\title{
DETERMINAN KINERJA PERBANKAN: STUDI EMPIRIS PADA BANK DI INDONESIA
}

\author{
Krismi Budi Sienatra \\ Universitas Ciputra
}

Diterima 22-01- 2020 / Disetujui 05-03-2020

\begin{abstract}
Bank performance is determined by many factors such as internal and external factors. This study aims to investigate the determinants of banking performance in Indonesia. By using samples from banks at the Indonesia Stock Exchange during the period 2013-2016 with a total of 32 banks. Internal factor variables used in this study include company size, capital ratios, deposit ratios, loan ratios, and non-performing loan ratios and banking performance using proxy return on assets and return on equity. The results of the study using linear regression analysis shows the results of the firm size ratio, capital ratio and non-performing loan ratio have an influence on profitability while the deposit ratio and lending ratio do not have an influence on bank performance either return on assets or return on equity.
\end{abstract}

Keyword : bank, profitability, credit risk, capital

\section{ABSTRAK}

Kinerja bank ditentukan oleh banyak faktor baik faktor internal atau eksternal. Penelitian ini bertujuan untuk menyelidiki faktor determinan kinerja perbankan di Indonesia. Penelitian ini mengambil sampel pada bank yang telah melantai di Bursa Efek Indonesia pada kurun periode 2013 - 2016 dengan total 32 bank. Variabel faktor internal yang digunakan dalam penelitian ini meliputi ukuran perusahaan, rasio modal, rasio deposito, rasio penyaluran kredit, dan rasio kredit macet serta kinerja perbankan menggunakan proksi return on asset dan return on equity. Hasil penelitian menggunakan analisis regresi linier menunjukkan hasil rasio ukuran perusahaan, rasio modal dan rasio kredit macet memiliki pengaruh terhadap profitabilitas sedangkan rasio deposito dan rasio penyaluran kredit tidak memiliki pengaruh terhadap kinerja perbankan baik return on asset atau return on equity.

Kata Kunci : bank, profitabilitas, risiko kredit, modal.

\section{PENDAHULUAN}

Bank memiliki peranan penting pada kegiatan perekonomian dalam tatanan masyarakat dan para ahli ekonom umumnya memiliki persepsi yang sama bahwa sektor perbankan yang sehat merupakan pemicu untuk pertumbuhan dan pengembangan ekonomi suatu negara secara terus menerus. Perbankan yang sehat juga berperan dalam kegiatan perekonomian sebagai perantara keuangan dengan mengkonversi tabungan deposito simpanan dari masyarakat menjadi investasi yang produktif dalam bentuk penyaluran kredit atau pinjaman. Bank dalam kedudukannya sebagai penghimpun dana dan penyedia dana merupakan penjamin stabilitas yang penting untuk sistem keuangan. Sistem keuangan yang efisien harus mencangkup perbaikan profitabilitas, peningkatan jumlah dana yang mengalir dari nasabah ke peminjam, dan memberikan kualitas pelayanan di jasa keuangan yang baik bagi pelanggan. Pentingnya bank profitabilitas dalam perekonomian dapat dinilai di tingkat mikro dan makro.

Pada level mikro, profitabilitas adalah prasyarat penting dari perbankan sebagai lembaga yang kompetitif. Oleh karena itu, tujuan dasar dari sebuah manajemen bank adalah untuk merealisasikan keuntungan untuk keberlangsungan bisnis. Eksistensi, pertumbuhan, dan kelangsungan hidup sebuah organisasi bisnis sebagian besar bergantung pada keuntungan yang mampu didapatkan. Pada tingkat makro, sektor perbankan yang memiliki fundamental profitabilitas yang baik mampu bertahan terhadap guncangan negatif dari ekonomi dan berkontribusi pada stabilitas sistem keuangan. Hubungan antara tingkat kesehatan sektor perbankan dan pertumbuhan ekonomi sudah banyak dikaji di banyak negara maju. 
Dengan demikian, pemahaman tentang faktorfaktor penentu profitabilitas bank adalah hal penting untuk diperhatikan karena kesejahteraan sektor perbankan sangat penting untuk kesejahteraan ekonomi pada umumnya.

Istilah "profitabilitas" mengacu pada kemampuan organisasi bisnis untuk memperoleh dan mempertahankan labanya dari tahun ke tahun. Kinerja profitabilitas bank menunjukkan keberhasilan manajemen dan hal tersebut adalah salah satu tolak ukur kinerja yang utama dan banyak diperhatikan untuk investor. Profitabilitas yang stabil dalam organisasi bisnis yang mencangkup hajat hidup orang banyak berkontribusi bagi kemajuan ekonomi serta sebagai keuntungan mempengaruhi investasi dan cadangan dana bagi perusahaan. Hal ini karena kenaikan keuntungan akan menambah arus kas perusahaan dan memberikan keleluasaan dalam sumber pendanaan yang lebih besar yaitu laba ditahan untuk investasi perusahaan.

Gambaran perekonomian Indonesia secara makro mengalami pelemahan yang ditunjukkan dengan pertumbuhan kurang dari 5 persen hingga semester pertama tahun 2015. Bank Indonesia selaku bank sentral bahkan memangkas proyeksi pertumbuhan ekonomi menjadi 4,9 persen saja untuk tahun 2015. Dalam kondisi yang lesu tersebut, Otoritas Jasa Keuangan (2016) sebagai badan pengawasan keuangan termasuk sektor perbankan menyatakan bahwa kondisi kesehatan bank secara umum masih bagus walaupun tahun 2015 mengalami perlambatan. Data OJK (2016) dari 118 bank yang ada, sebagian besar memiliki rating II atau bagus dan hanya sekitar 10 persen yang rating III atau standar. Walaupun perlamabatan terjadi, pada Juni 2015 pertumbuhan industri perbankan masih ada yakni kredit tumbuh 4,18 persen pada tahun berjalan yang masih terdapat pertumbuhan walaupun tidak secepat semester pertama tahun 2015. Dari sisi rasio kecukupan modal (capital adequacy ratio) 118 bank, menurut profil risiko kisarannya berada di angka 10 - 14 persen. Artinya, profil risiko dari rasio kecukupan modal bank semuanya memenuhi minimal rasio kecukupan modal yang ditetapkan minimal sebesar 8 persen.
Banyak peneliti di bidang ekonomi, manajemen strategis, dan akuntansi keuangan telah berusaha untuk mengidentifikasi variasi sumber-sumber yang mempengaruhi tingkat profitabilitas bank. Beberapa penelitian telah dilakukan di beberapa negara (Garcia dan Guerreiro, 2016 ; Menicucci dan Paolucci, 2016 Bertin et al., 2014 ; Sufian dan Noor, 2012 ) yang menyelidiki determinan profitabilitas bank. Identifikasi faktor penentu tersebut tersebut sangat penting untuk keberhasilan manajemen bank terutama ketika mengalami saat krisis dan untuk menarik potensi investor nasional dan internasional. Hal ini juga diketahui bahwa pertumbuhan profitabilitas mungkin faktor yang paling penting dari kenaikan nilai pemegang saham. Dari beberapa penelitian terdahulu yang telah dilakukan, ditarik kesimpulan utama yang muncul dari sebagian besar penelitian adalah bahwa faktor internal dapat sebagian besar mempengaruhi kinerja bank. Meskipun telah ada hasil riset terbaru yang memeriksa profitabilitas sektor keuangan di negara-negara maju seperti yang dilakukan Menicucci dan Paolucci (2016) serta Garcia dan Guerreiro (2016), studi empiris pada faktor-faktor mempengaruhi kinerja lembaga keuangan dalam perekonomian di negara berkembang khususnya Asia Tenggara masih sedikit. Tujuan dari penelitian ini dilakukan guna mengetahui faktor-faktor internal penentu profitabilitas bank di Indonesia, terutama pada masa perlambatan ekonomi yang terjadi pada tahun 2015 hingga 2016 dimana realisasi pertumbuhan ekonomi tidak mencapai target.

\section{Tinjauan Literatur}

Peneliti menemukan ada beberapa studi yang meneliti tentang dampak karakteristik perusahaan terhadap profitabilitas, yang dimulai dari sejak awal oleh Short (1979) dan Bourke (1989), sejumlah studi yang lebih baru memiliki berusaha untuk mengidentifikasi beberapa faktor penentu utama dari profitabilitas bank di banyak negara. Beberapa studi mengkhususkan pada satu negara seperti India, Kuwait, dan Portugal (Al Omar and Al Mutairi, 2008 ; Sufian and Noor. 2012 ; Garcia and Guerreiro. 2016 ;), sementara beberapa dari mereka menggunakan data panel negara untuk jangkauan yang lebih luas yaitu kawasan regional Eropa dan Amerika 
Latin (Menicucci dan Paolucci, 2016 ; Bertin et al., 2014) .

Hasil penelitian empiris tersebut menghasilkan temuan yang berbeda dan belum menunjukkan adanya konsistensi hasil karena perbedaan data, periode waktu dan negaranegara diselidiki. Terlepas dari satu negara atau penelitian berbasis panel, penelitian yang telah dilakukan sebelumnya dalam menyelidiki profitabilitas perbankan mengungkapkan banyak faktor yang mempengaruhinya. Faktor-faktor ini diklasifikasikan dalam dua kategori utama, yaitu hal-hal yanng dibawah kendali manajemen atau faktor internal dan hal-hal yang berada diluar kendali manajemen atau faktor eksternal. Dalam hal ini, penelitian yang lebih baru dari Garcia dan Guerrerio (2016) memisahkan faktor manajerial yang dibedakan dari tindakan manajerial dalam mengambil kebijakan tentang tindakan bank di masa depan dan sejumlah faktor eksternal seperti inflasi yang mempengaruhi profitabilitas bank. Studi lain oleh Athanasoglou et al. (2006) dan Athanasoglou et al. (2008) dari determinan profitabilitas bank di kawasan Eropa bagian tenggara menemukan bahwa determinan dari faktor eksternal tertentu memiliki pengaruh yang signifikan terhadap profitabilitas bank. Faktor internal profitabilitas bank secara umum dipengaruhi oleh strategi dan keputusan manajemen yang berkaitan dengan sumber dana, penggunaan manajemen dana, modal, likuiditas, dan biaya manajemen yang dicerminkan dari tingkat likuiditas, kebijakan penetapan, efisiensi operasional, kecukupan modal, biaya manajemen dan ukuran bank.

Di sisi lain, faktor-faktor penentu eksternal adalah variabel yang tidak berhubungan dengan manajemen bank dan umumnya mereka mencerminkan lingkungan makroekonomi dan hukum baik industri yang mempengaruhi operasional perusahaan dan kinerja lembaga keuangan, yaitu pertumbuhan ekonomi, inflasi dan kapitalisasi pasar. Beberapa studi terbaru mengenai kelompok kedua ini penentu difokuskan juga pada dampak peraturan terhadap kinerja bank (Barth et al., 2003, 2004), tetapi bukti yang dihasilkan masih lemah dimana struktur bank dan peraturan pengawasan mempengaruhi keuntungan bank. Dalam beberapa kajian riset terdahulu, profitabilitas bank biasanya ditentukan oleh faktor internal dan eksternal. Determinan internal profitabilitas yang secara empiris juga dieksplorasi dan sebagian besar penelitian sebelumnya telah menyatakan bahwa ukuran perusahaan (Garcia dan Guerreiro, 2016 ; Menicucci adan Paolucci, 2016), rasio modal (Molyneux dan Thorton, 1992), rasio likuiditas (Bourke, 1989; Molyneux dan Thorton, 1992), kualitas aset dan efisiensi operasional bank merupakan faktor penting dalam mencapai profitabilitas yang tinggi. Hasil dari pemakaian campuran determinan internal dicapai dalam literatur sebelumnya menyebabkan pemahaman yang jelas tentang efek faktor internal pada profitabilitas bank dan kemudian peningkatan minat terhadap ini subyek. Berdasarkan sifat dan tujuan dari masing-masing studi yang disebutkan dalam tinjauan literatur, sejumlah variabel diusulkan sebagai determinan internal profitabilitas bank. Secara khusus, faktor penentu internal yang dipertimbangkan dalam penelitian ini adalah: ukuran perusahaan, rasio modal, rasio pinjaman, rasio kredit, dan rasio kredit macet.

\section{Perumusan Hipotesis}

Salah satu pertanyaan yang paling penting dan yang sering muncul dari kajian yang telah ada tentang apakah ukuran sebuah perusahaan mampu memaksimalkan profitabilitas atau kinerja bank. Kajian hubungan antara besarnya ukuran perusahaan dan profitabilitas telah diteliti dalam beberapa penelitian sebelumnya dan banyak bukti dalam penelitian empiris sebelumnya mengkonfirmasi peran ukuran perusahaan sebagai salah satu faktor yang menentukan profitabilitas bank. Setelah meninjau penelitian mengenai hubungan antara ukuran perusahaan dan profitabilitas, beberapa hasil penelitian empiris terdahulu masih ada hasil berbeda yang ditemukan. Penelitian yang dilakukan oleh Athanasoglou et al. (2008), Saeed (2014), serta Menicucci and Paolucci (2016) menemukan hasil positif dari pengaruh ukuran perusahaan terhadap profitabilitas bank yang mereka selidiki. Para peneliti tersebut mengkaitkan bahwa ukuran yang semakin besar semakin baik terhadap 
profitabilitas bank karena bank-bank besar bisa mendapatkan keuntungan dari skala ekonomi dan memungkinkan pengurangan biaya. Bank yang besar juga memungkinkan mendapat manfaat dari skala ekonomi dengan pengurangan risiko dengan pinjaman dan diversifikasi produk, sehingga memberikan akses ke pasar di mana kecil bank tidak bisa masuk. Maka hipotesis pertama yang dibangun dalam penelitian ini adalah

\section{H1 : Ukuran perusahaan berpengaruh terhadap profitabilitas bank}

Rasio modal adalah ukuran yang digunakan untuk menilai kecukupan modal, dan menilai kesehatan bank secara umum, karena mewakili seberapa baik nilai kapitalisasi bank tersebut. Rasio modal digunakan dalam model penelitian ini untuk mengetahui adanya keterkaitan antara kapitalisasi bank dengan profitabilitas perusahaan. Dengan demikian, rasio ekuitas terhadap rasio total aset (yaitu rasio modal) dianggap sebagai salah satu dasar mengukur kekuatan modal (Golin, 2001), dan modal bank juga banyak digunakan untuk menganalisis status kekuatan keuangan bank. Terutama di negara-negara berkembang, struktur permodalan dengan komposisi yang kuat sangat penting untuk lembaga keuangan, karena akan memberikan fondasi yang kuat untuk menghadapi krisis ketika terjadi dan untuk mengkonsolidasikan keamanan dana untuk para nasabah selama kondisi ekonomi makro yang tidak stabil. Bank dengan struktur modal yang lemah hampir tidak bisa menahan situasi ekonomi yang rawan dan adalah sebuah hal yang penting untuk lembaga keuangan untuk mempertahankan kekuatan yang lebih tinggi dari struktur modal untuk menanggung kerugian dan untuk mengurangi bahwakn menghentikan risiko kebangkrutan selama masa-masa sulit. Penelitian yang paling awal diketahui dalam studi profitabilitas perbankan di 18 negara Eropa untuk periode 1986-1989 oleh Molyneux dan Thorton (1992) berpendapat bahwa dampak kinerja rasio modal bank adalah positif dalam kaitannya dengan kesehatan bank-bank BUMN di negara Eropa. Athanasoglou et al. (2008) meneliti perbankan di negara Yunani, Bertin et al. (2014) meneliti di kawasan Amerika Latin serta Garcia dan Guerreiro (2016) meneliti di kawasan Portugal dan menemukan hasil yang sama yaitu rasio modal memiliki hubungan positif dengan kinerja perbankan. Maka hipotesis kedua dalam penelitian adalah :

H2 : Rasio modal berpengaruh terhadap profitabilitas bank

Disamping rasio modal, penelitian ini menyertakan aset dan rasio komposisi utang atau liabilitas sebagai penentu internal kinerja bank. Dalam hal ini, volume pinjaman dan deposito digunakan untuk mengukur efisiensi aset dan kewajiban manajemen portofolio. Sesuai dengan literatur sebelumnya rasio kredit dianggap sebagai indikator likuiditas, dan banyak literatur menemukan hubungan positif antara likuiditas dan profitabilitas (Bashir, 2003; Sufian dan Habibullah, 2009). Sebuah bank yang memiliki rasio kredit yang tinggi cenderung memiliki keuntungan yang tinggi pula. Hal ini dikarenakan pinjaman adalah sumber utama dari pendapatan dan diperkirakan memiliki dampak positif pada kinerja bank. Meskipun pinjaman bank merupakan sumber utama dari imbal hasil dan diharapkan mempengaruhi keuntungan positif, bukti dari berbagai penelitian mengungkapkan korelasi negatif antara pinjaman bank dan keuntungan. Ketika bank meningkatkan portofolio pinjaman mereka, bisa diasumsikan bahwa mereka harus membayar biaya atas untuk ketentuan pendanaan mereka. Dalam hal ini, rasio pinjaman yang sangat tinggi bisa menyiratkan bahwa bank telah mengalami pertumbuhan portofolio pinjaman yang cepat yang diikuti dengan membayar biaya yang lebih tinggi karena kebutuhan dana, dan keadaan ini dapat menyebabkan efek negatif pada profitabilitas. Berdasarkan penjelasan tersebut maka hipotesis ketiga dalam penelitian ini adalah sebagai berikut :

\section{$H 3$ : Rasio kredit berpengaruh terhadap} profitabilitas perbankan

\begin{tabular}{ccc} 
Dalam & \multicolumn{2}{c}{ operasionalnya bank } \\
mengandalkan simpanan nasabah untuk
\end{tabular} mengalokasikan kredit untuk nasabah lain. Dengan demikian, deposito yang dihimpun dari nasabah disalurkan untuk pinjaman kredit kepada nasabah lain yang kemudian diharapkan 
akan dapat menghasilkan keuntungan lebih dari hasil bunga yang dibayarkan. Argumen ini digarisbawahi oleh Lee dan Hsieh (2013) dengan menyimpulkan bahwa deposito yang tinggi akan memproduksi lebih banyak keuntungan, sedangkan deposito yang rendah dapat berdampak negatif pada profitabilitas mereka. Oleh karena itu, simpanan nasabah berhubungan positif dengan profitabilitas bank, namun di sisi lain ketidakmampuan bank dalam menyalurkan uang melalui pinjaman dapat mengurangi tingkat profitabilitas karena kepentingan dibayarkan kepada deposan. Namun, dampak pada profitabilitas yang berasal dari pertumbuhan deposito tergantung pada beberapa faktor. Pertama, dampak dipengaruhi oleh kemampuan bank untuk mengubah kewajiban deposito menjadi aset penghasil pendapatan, yang juga mengungkapkan efisiensi operasional bank. Efeknya juga tergantung pada kualitas kredit aset ini karena efek positif pada profitabilitas bank secara teratur dicapai dengan berinvestasi di aset kualitas kredit yang lebih tinggi. Bukti empiris dari Ben Naceur dan Goaied (2001) menunjukkan bahwa bank yang berkinerja terbaik adalah bank yang telah mengedepankan rekening deposito terkait dengan aset mereka. Meningkatkan deposito (yaitu rasio total simpanan terhadap total aset) menyiratkan pertumbuhan dana yang tersedia untuk penggunaan aktivitas menguntungkan yang berbeda seperti kegiatan pemberian kredit dan investasi. Dari penjelasan diatas maka hipotesis keempat dalam penelitian ini adalah :

\section{H4 : Deposito berpengaruh positif terhadap profitabilitas perbankan}

Rasio provisi kerugian kredit terhadap total kredit sekarang dianalisis untuk mengukur pengaruh kualitas aset bank pada profitabilitas. Rasio penyisihan kerugian kredit atau pinjaman merupakan indikator kualitas aset bank, dan itu menunjukkan perubahan dalam kinerja masa depan. Sebuah rasio yang lebih tinggi menunjukkan berkurangnya kualitas kredit dan menyebankan profitabilitas yang lebih rendah. Dampak negatif kerugian cadangan kredit pada profitabilitas bank akan menyarankan berkurangnya kualitas kredit yang menaikkan biaya provisi dan menurunnya pendapatan bunga. Dengan demikian, kerugian pinjaman ketentuan untuk rasio total pinjaman diharapkan memiliki hubungan negatif dengan bank profitabilitas. Jika bank beroperasi di lingkungan yang lebih berisiko dan tidak pasti dan mereka merasa sulit untuk mengendalikan pinjaman operasional mereka yang mungkin akan menyebabkan kerugian pinjaman yang lebih tinggi daripada rasio penyediaan. Kemudian tingkat yang lebih tinggi dari pasokan kerugian kredit bisa menciptakan kekhawatiran mengenai memaksimumkan keuntungan kekuatan bank. Perubahan risiko kredit dapat mencerminkan perubahan dalam kesehatan portofolio pinjaman bank (Cooper et al., 2003), yang dapat mempengaruhi kinerja lembaga. Dalam hal ini, Menicucci dan Paolucci (2016) mengklaim bahwa modifikasi dalam profitabilitas bank terutama karena variasi risiko kredit. Penguatan eksposur risiko kredit umumnya terkait dengan mengurangi profitabilitas perusahaan. Dari penjelasan tersebut maka hipotesis kelima dalam penelitian ini adalah :

H5 : Kredit macet berpengaruh terhadap profitabilitas bank

\section{METODE PENELITIAN}

Penelitian ini menguji variabel yang menjadi determinan profitabilitas bank di Indonesia, data time series digunakan untuk dianalisis dengan menggunakan persamaan regresi berganda. Populasi dalam penelitian ini adalah seluruh perusahaan perbankan di Indonesia yang terdaftar di Bursa Efek Indonesia pada kurun waktu tahun 2013 hingga 2016. Sampel diambil dengan teknik purposive sampling yaitu bank yang beroperasional selama 4 tahun terakhir dan mempublikasikan laporan keuangannya dengan jumlah akhir sebanyak 33 perusahaan. Pada bagian ini peneliti menjelaskan kedua variabel dependen dan independen yang dipilih untuk menganalisis faktor-faktor yang mempengaruhi profitabilitas bank. Variabel profitabilitas sebagai variabel dependen menggunakan proxy return on asset (ROA) dan return on equity (ROE) seperti yang dipakai oleh banyak penelitian empiris terdahulu. Return on asset mencerminkan kemampuan manajemen bank untuk menghasilkan laba dari penggunaan aktiva, dan itu menunjukkan seberapa efektif 
sumber bank dikelola untuk menghasilkan keuntungan. Pada prinsipnya, return on asset mengukur keuntungan yang diperoleh per rupiah aset dan itu mencerminkan kemampuan manajemen bank dan efisiensi dalam menggunakan sumber daya keuangan dan investasi bank untuk menghasilkan pendapatan.

Sebagai penentu potensi profitabilitas bank-bank di Indonesia, peneliti mempertimbangkan hanya lima variabel independen yang spesifik digunakan. Tepatnya, faktor internal yang digunakan sebagai penentu kinerja internal adalah ukuran total aset bank yang mewakili ukuran bank (SIZE), rasio ekuitas terhadap total aset yang mewakili kekuatan modal atau capital adequacy ratio (CAR), pinjaman kredit terhadap total aset (LOAN), total simpanan terhadap total aset (DEPO) dan rasio kredit macet atau non performing loan (NPL). Penelitian menggunakan regresi berganda dalam melakukan analisis dengan persamaan :

ROA $=\mathrm{a}+\mathrm{bSIZE}+\mathrm{bCAR}+\mathrm{bLOAN}+\mathrm{bDEPO}$ $+\mathrm{bNPL}+\mathrm{e}$

$\mathrm{ROE}=\mathrm{a}+\mathrm{bSIZE}+\mathrm{bCAR}+\mathrm{bLOAN}+\mathrm{bDEPO}$ $+\mathrm{bNPL}+\mathrm{e}$

\section{HASIL DAN PEMBAHASAN}

Tabel 1 menunjukkan hasil statistik deskriptif dari variabel dependen dan independen penelitian ini. Kinerja perbankan yang ditunjukkan dalam ROA memberikan rata-rata tingkat return perbankan di Indonesia pada angka 0.010524 atau sekitar $1 \%$ dengan nilai tertinggi pada angka 0.0982 atau $9.82 \%$ dan nilai terendahnya sebesar -0.1177 atau sekitar $11,77 \%$. Hal ini menandakan bahwa kinerja perbankan secara umum di Indonesia dalam kurun waktu tahun 2013-2016 tidak terlalu bagus karena nilai ROA yang rata-rata sebesar $1 \%$ tidak terlalu baik jika dibandingkan dengan rata-rata industri di sektor lain. Rasio kecukupan modal atau CAR untuk perbankan di Indonesia memiliki nilai rata-rata sebesar 0.132352 atau sekitar $13.23 \%$. Rata-rata profitabilitas menggunakan Return on equity menunjukkan hasil yang lebih baik dimana angka rata rata sebesar $7 \%$ yang Besarnya rata-rata CAR ini cukup bagus karena aturan batas minimal rasio kecukupan modal untuk bank di Indonesia yang ditetapkan oleh peraturan Bank Indonesia tahun 2001 adalah dikisaran $8 \%$ sehingga sudah diatas batas minimal.

Tabel 1. Statistik Deskriptif

\begin{tabular}{|l|r|r|r|r|r|}
\hline \multicolumn{1}{|c|}{ Variabel } & \multicolumn{1}{c|}{ N } & Minimum & Maximum & \multicolumn{1}{c|}{ Mean } & \multicolumn{1}{c|}{ Std. Deviation } \\
\hline CAR & 132 & .0521 & .2601 & .132352 & .0388958 \\
LOAN & 132 & .3183 & .8071 & .634364 & .0854231 \\
DEPO & 132 & .5925 & .8929 & .773041 & .0611921 \\
NPL & 132 & .0006 & .1233 & .020411 & .0192058 \\
SIZE & 132 & 12.11 & 15.02 & 13.5954 & .72941 \\
ROA & 132 & .1177 & .0982 & .010524 & .0247069 \\
ROE & 132 & -1.0784 & .5225 & .070423 & .2091779 \\
\hline
\end{tabular}

yang semakin besar pula. Variabel simpanan

Rasio penyaluran kredit untuk perbankan di Indonesia memiliki nilai rata-rata 0.634364 atau sebesar $63.43 \%$ dimana nilai minimum sebesar $31.83 \%$ dan nilai maksimumnya sebesar 80.71 $\%$ yang menandakan bahwa penyaluran kredit yang dilakukan oleh perbankan di Indonesia sudah cukup bagus karena perlu diingat bahwa salah satu pendapatan bank bersumber dari bunga yang diperoleh dari penyaluran kredit. Bank yang semakin besar dalam menyalurkan kredit berpotensi untuk memperoleh pendapatan atau DEPO adalah deposito yang dihimpun dari nasabah atau pihak ketiga disalurkan untuk pinjaman kredit kepada nasabah lain yang kemudian diharapkan akan dapat menghasilkan keuntungan lebih dari hasil bunga yang dibayarkan. Nilai rata-rata DEPO untuk perbankan di Indonesia sebesar 0.773041 yang artinya $77.3 \%$ dari modal bank berasal dari dana yang dihimpun dari pihak ketiga atau masyarakat. Variabel non performing loan atau kredit macet yaitu NPL memiliki nilai rata-rata 
sebesar 0.020411atau sebesar $2.04 \%$. Hal ini menunjukkan dari total penyaluran kredit yang diberikan hanya sebesar $2.04 \%$ yang mengalami kredit macet atau tidak dapat ditagih. Perbankan di Indonesia sangat baik dalam mengelola kredit macetnya yang dibuktikan dengan rasio NPL yang sangat kecil.

Tabel 2. Hasil Uji Regresi Linier Terhadap Return on Asset

\begin{tabular}{|l|r|r|r|l|}
\hline \multicolumn{1}{|c|}{ Variabel } & $\begin{array}{c}\text { Standardized } \\
\text { Coefficients Beta }\end{array}$ & t hitung & p value & \multicolumn{1}{|c|}{ Keterangan } \\
\hline SIZE & .645 & 8.650 & .000 & signifikan \\
\hline CAR & .289 & 4.039 & .000 & signifikan \\
\hline LOAN & .000 & -.004 & .997 & tidak signifikan \\
\hline DEPO & .147 & 1.847 & .067 & tidak signifikan \\
\hline NPL & -.624 & -9.632 & .000 & signifikan \\
\hline
\end{tabular}

Tabel 3. Hasil Uji Regresi Linier Terhadap Return on Equity

\begin{tabular}{|l|r|r|r|l|}
\hline \multicolumn{1}{|c|}{ Variabel } & $\begin{array}{c}\text { Standardized } \\
\text { Coefficients Beta }\end{array}$ & t hitung & p value & \multicolumn{1}{|c|}{ Keterangan } \\
\hline SIZE & .596 & 7.448 & .000 & signifikan \\
\hline CAR & .288 & 3.750 & .000 & signifikan \\
\hline LOAN & -.043 & -.645 & .520 & tidak signifikan \\
\hline DEPO & .098 & 1.154 & .251 & tidak signifikan \\
\hline NPL & .596 & -8.190 & .000 & signifikan \\
\hline
\end{tabular}

Hasil regresi menunjukkan bahwa variabel SIZE berpengaruh terhadap terhadap profitabilitas yang diukur menggunakan return on asset dan return on equity. Hal ini menunjukkan bahwa bank-bank besar lebih baik dari bank yang yang lebih kecil dalam mencapai return on asset yang lebih tinggi. Hasil ini adalah konsisten dengan bukti sebelumnya (Pasiouras dan Kosmidou, 2007; Staikouras et al., 2008; Molyneux dan Thorton, 1992; Bikker dan Hu, 2002; Goddard dkk, 2004; Gul et al., 2011). Secara khusus, banyak peneliti menemukan bahwa penghematan biaya dapat diraih dengan meningkatkan ukuran aset perbankan (Berger et al., 1987), sementara yang lain digambarkan skala ekonomi tinggi sebuah bank yang diukur dari besar asetnya (Shaffer, 1985). Kembali lagi dari ukuran perusahaan merupakan besar dari total nilai aset yang dimiliki. Aset dari bank digunakan untuk kegiatan operasional dalam aktivitasnya khususnya melakukan layanan menghimpun dana dan menyalurkan kredit. Oleh karena itu sebuah bank yang memperluas operasinya akan memunculkan peluang pertumbuhan yang lebih besar profitabilitas bank.

Penjelasan tentang hubungan positif yang dilihatn dari koefisiennya antara ukuran dan profitabilitas berhubungan dengan skala ekonomi) karena bank yang berukuran besar berkaitan dengan memiliki potensi menguasai pasar karena bank yang memiliki aset dalam jumlah besar umumnya menguasai porsi yang lebih besar di pasar, meningkatkan keuntungan melalui alokasi biaya tetap yang sama dengan volume yang lebih besar (Pasiouras dan Kosmidou, 2007; Staikouras et al., 2008). Posisi ini memungkinkan bank tersebut membayar lebih sedikit biaya tetap dan untuk mendapatkan modal yang lebih banyak dari simpanan nasabah yang dihimpun dari pihak ketiga. Di sisi lain hal juga menunjukkan bahwa bank-bank besar mampu mendapatkan keuntungan dari peluang diversifikasi produk dan pinjaman yang lebih tinggi (Bikker dan Hu, 2002). Untuk alasan ini, biaya tetap bank yang skala ukurannya besar 
mungkin menjadi lebih rendah dibanding bankbank yang berukuran lebih kecil.

Untuk pengujian hipotesis kedua, rasio kecukupan modal atau capital adequacy ratio (CAR) berpengaruh positif terhadap profitabilitas yang diukur return on asset dan return on equity, yang berarti bahwa bank-bank yang rasio kecukupan modalnya tinggi memiliki tingkat pengembalian aktiva dan modal yang lebih tinggi, sehingga mengurangi biaya pendanaan dan peluang menghadapi risiko kebangkrutan menjadi lebih rendah. Sebaliknya, rasio modal yang rendah menyiratkan risiko yang lebih besar dan biaya pinjaman yang lebih tinggi. Jumlah ekuitas yang meningkat akan memungkinkan bank untuk mengurangi tingkat hutang mereka sehingga biaya modal dari bankbank ini menjadi lebih rendah karena tidak mengandalkan dari utang ataupun simpanan. Oleh karena itu, menjadi hal yang wajar jika tingkat profitabilitas harus lebih tinggi untuk kapitalisasi bank yang lebih baik. Hasil juga menunjukkan nilai koefisien yang positif baik pada return on asset maupun return on equity yang mencerminkan bahwa sektor perbankan di Indonesia kuat. Hal ini didukung dengan ratarata rasio kecukupan modal sebesar 13,23\% yang diatas rata-rata batas minimal dari rasio kecukupan modal sebesar 8\%. Penelitian ini selaras dengan hasil penelitian yang dilakukan Menicucci dan Paolucci (2016), Bertin. et al., (2014) dan Saeed (2014).

Hipotesis tentang rasio pinjaman (LOAN) menunjukkan bahwa rasio pinjaman tidak memiliki pengaruh terhadap profitabilitas perbankan di Indonesia baik yang diukur dengan return on asset atau return on equity. Ini menunjukkan bahwa rasio pinjaman yang lebih banyak tidak meningkatkan peluang untuk mencapai profitabilitas yang lebih tinggi. Hasil yang tidak signifikan ini mungkin disebabkan karena persepsi tentang kekhawatiran bahwa bank hanya sebatas memainkan peran perantara antara kreditor dan peminjam, dimana simpanan yang dihimpun dari pihak ketiga disalurkan menjadi pinjaman kepada masyarakat yang membutuhkan dan nantinya bank akan menerima bunga sebagai ganti biaya modal. Persepsi bank di Indonesia sebagai sebatas lembaga yang menghimpun dana masyarakat juga masih dialami oleh perbankan di Eropa. Pendapat ini diperkuat oleh penelitian Menicucci dan Paolucci pada tahun 2016 dimana menemukan hasil serupa tidak adanya pengaruh signifikan serta menemukan hasil pengamatan dimana bank hanya sebatas lembaga penghimpun dana masyarakat.

Hasil mengenai variabel DEPOSIT menunjukkan tidak adanya pengaruh terhadap profitabilitas bank baik yang diukur dengan return on asset ataupun return on equity. Dukungan bahwa bank tergantung pada deposito untuk mendapatkan pendanaan mereka agar dapat mencapai profitabilitas yang lebih baik tidak tercapai. Deposito yang berlebih akan meningkatkan kapasitas pinjaman dan secara tidak langsung berdampak pada perolehan keuntungan yang lebih tinggi. Permintaan pinjaman yang meningkat akan mendorong bank untuk menghimpun dana dari masyarakat, yang pada akhirnya profitabilitas pun membesar karena bank menemukan peluang investasi yang menarik untuk memberikan pinjaman melalui deposito (Naceur dan Goaied, 2001). Namun hasil pada penelitian ini tidak signifikan yang mengindikasikan bahwa perbankan di Indonesia belum mampu untuk menggunakan hasil dana yang dihimpun dari masyarakat untuk menghasilkan laba khususnya ketika kondisi ekonomi suatu negara mengalami perlambatan atau krisis (Garcia dan Guerreiro, 2016), dimana Indonesia pada tahun 2015 mengalami perlambatan pertumbuhan ekonomi dimana pertumbuhan tidak bisa mencapai 2015. Sedikit banyak hal ini akan mempengaruhi performa bank dalam menyalurkan kredit dan menghasilkan keuntungan karena ekonomi yang melambat akan menurunkan pinjaman permodalan masyarakat ke bank. Penelitian ini sejalan yang dilakukan oleh Garcia dan Guerreiro (2016) yang menghasilkan tidak adanya hubungan signifikan yang di perbankan Portugal ketika kondisi krisis.

Hasil regresi menunjukkan rasio kredit macet atau non performing loan (NPL) berpengaruh signifikan negatif terhadap profitabilitas baik return on asset maupun return on equity. Hasil penelitian ini didukung oleh Menicucci dan Paolucci (2016) yang menemukan adanya pengaruh signifikan negatif pada sektor perbankan di Eropa dan juga penelitian Bertin et al., (2014) yang meneliti di 
Amerika Latin. Secara teoritis peningkatan eksposur terhadap risiko kredit biasanya akan terkait dengan penurunan profitabilitas perusahaan oleh karenanya diharapkan terjadi hubungan negatif antara profitabilitas dan non performing loan. Dalam hal ini perbankan di Indonesia harus lebih berkonsentrasi pada pengawasan pengelolaan risiko kredit. Cara yang dapat dilakukan oleh bank - bank di Indonesia untuk mengurangi masalah ini adalah dengan memperkuat transparansi sistem keuangan, yang akan mendukung lembaga keuangan untuk menilai risiko kredit dengan lebih akurat. Temuan ini menyarankan agar bank-bank di Indonesia untuk melakukan penyaringan dan pemantauan risiko kredit yang lebih efisien dengan demikian akan memperbaiki peramalan risiko gagal bayar di masa depan.

Sistem perbankan yang sehat dan solid secara finansial merupakan salah satu dasar keberlanjutan pertumbuhan ekonomi. Dalam hal ini, sektor perbankan Indonesia menunjukkan keberhasilan kinerja meskipun adanya perlambatan ekonomi di Indonesia pada tahun 2015. Subjek ini membentuk tujuan penelitian dalam lingkup ini, faktor penentu profitabilitas bank yang dianalisis dalam model regresi berganda dengan menggunakan sampel terdiri dari semua bank di Indonesia yang terdaftar di pasar bursa selama periode tahun 2013 hingga 2016. Temuan empiris analisis menunjukkan bahwa semua variabel internal secara statistik berpengaruh terhadap profitabilitas baik ukuran perusahaan (SIZE), rasio kecukupan modal (CAR), dan rasio kredit macet (NPL) kecuali rasio simpanan (DEPO) dan rasio penyaluran kredit (LOAN) yang memiliki hasil tidak signifikan.

\section{SIMPULAN DAN SARAN}

Temuan dalam penelitian ini memiliki implikasi dimana pertama, hasil dari penelitian ini memberikan wawasan baru yang lebih mendalam dalam menentukan profitabilitas bank di Indonesia. Karakteristik yang berbeda pada perbankan di Indonesia masih menunjukkan fungsi bank yang sebatas masih menghimpun dana dari masyarakat kemudian menyalurkan kembali kedalam bentuk pinjaman. Kedua penelitian ini bisa memberikan masukkan kepada bank, pemerintah, pemangku kepentingan, dan investor dalam proses pengembalian keputusan khususnya untuk investor luar negeri untuk mencari peluang investasi yang menguntungkan di sektor keuangan khususnya perbankan di Indonesia dimana sektor keuangan memiliki sensitivitas dan nilai pasar yang paling besar di pasar bursa Indonesia.

Dari studi empiris yang dilakukan ini dapat memperluas literatur yang ada dalam meneliti profitabilitas perbankan yang telah ada dimana penelitian ini memberikan gambaran untuk konteks Indonesia sebagai negara berkembang yang berbeda dengan negara maju kawasan Eropa. Penelitian di masa depan dapat dikembangkan dengan menganalisis variabel lebih lanjut yang tidak disertakan dalam penelitian ini khususnya faktor internal seperti biaya operasional bank dan faktor eksternal seperti merger karena perbankan di Indonesia cukup banyak yang terjadi merger guna memperluas jaringan, menyatukan aset, ataupun menghindari kebangkrutan.

Penelitian ini memiliki keterbatasan dimana durasi tahun pengamatan yang relatif pendek yaitu selama empat tahun terakhir karena data sebelum tahun 2013 sulit untuk diakses serta belum menyertakan bank yang ukurannya belum besar yang ditandai belum terdaftar di lantai bursa. Temuan penelitian ini memiliki relevansi kebijakan yang cukup besar khususnya pada sektor perbankan. Kemampuan untuk memaksimalkan hasil investasi yang disesuaikan dengan risiko merupakan elemen penting untuk menjaga daya saing dari sektor perbankan Indonesia. Keberhasilan sektor perbankan Indonesia bergantung pada efisiensi, profitabilitas dan daya saingnya. Untuk mencapai tujuan ini perlu mengidentifikasi faktor-faktor penentu profitabilitas dari kesuksesan bank untuk merumuskan kebijakan guna mengintensifkan dan mempertahankan faktor-faktor yang menjadi kekuatan dan stabilitas sektor perbankan di Indonesia. Adanya keterkaitan sektor perbankan yang sehat dan pertumbuhan ekonomi (Rajan dan Zingales, 1995), menimbulkan perlunya kesadaran pengetahuan tentang faktor-faktor fundamental bank dan bagi pemangku kepentingan seperti otoritas pengatur dan pengawas perbankan perlu merumuskan kebijakan masa depan guna memaksimalkan kinerja perbankan sebagai penggerak ekonomi suatu negara. 


\section{DAFTAR PUSTAKA}

Al Omar., H., and Al Mutairi., A., (2008),"BankSpecific Determinants of Profitability: The case of Kuwait", Journal of Economic and Administrative Sciences, Vol. 24 No 2 pp. $20-34$

Athanasoglou, P.P., Delis, S.N. and Staikouras, C.K. (2006),"Determinants of bank profitability in the South Eastern European Region", Mediterranean Journal of Social Sciences, Vol. 2 No. 1, pp. 58-78.

Athanasoglou, P.P., Brissimis, S.N. and Delis, M.D. (2008), "Bank-specific, industryspecific and macroeconomic determinants of bank profitability", Journal of International Financial Markets, Institutions and Money, Vol. 18 No. 2, pp. 121-136.

Barth, J.R., Caprio, G. Jr. and Levine, R. (2004), "Bank regulation and supervision: what works best?", Journal of Financial Intermediation, Vol. 13 No. 2, pp. 205-

Barth, J.R., Nolle, D.E., Phumiwasana, T. and Yago, G. (2003), "A cross-country analysis of the bank supervisory framework and bank performance", Financial Markets, Institutions \& Instruments, Vol. 12 No. 2, pp. 67-120.

Bashir, A.H. (2003), "Determinants of profitability in Islamic Banks: some evidence from the middle east", Islamic Economic Studies, Vol. 11 No. 1, pp. 3157.

Bertin. J.M., Moya. J.A., and Perales., A.R, (2014)," Determinants of bank performance: evidence for Latin America ", Academia Revista Latinoamericana de Administración, Vol. 27 Iss 2 pp. 164 182

Bikker, J. and Hu, H. (2002), "Cyclical patterns in profits, provisioning and lending of banks and procyclicality of the New Basel
Capital Requirements", BNL Quarterly Review, Vol. 221 No. 1, pp. 143-175.

Bourke, P. (1989), "Concentration and other determinants of bank profitability in Europe, North America and Australia", Journal of Banking and Finance, Vol. 13 No. 1, pp. 65-79.

Cooper, M., Jackson, W. and Patterson, G. (2003), "Evidence of predictability in the cross-section of bank stock returns", Journal of Banking and Finance, Vol. 27 No. 5, pp. 817-850.

Garcia., M.T.M. and Guerreiro. (2016),"Internal and external determinants of banks' profitability: The Portuguese case", Journal of Economic Studies, Vol. 43 Iss 1 pp. $90-107$

Laryea, E., Matthew Ntow-Gyamfi., Alu A. A., (2016)," Nonperforming loans and bank profitability: evidence from an emerging market ", African Journal of Economic and Management Studies, Vol. 7 Iss 4 pp. $462-481$

http://rimanews.com/ekonomi/keuangan/read/20 150828/231223/Ekonomi-Melemah-Begini-

Kondisi-Perbankan-Indonesia diakses

http://www.ojk.go.id/id/kanal/perbankan/datadan-statistik/statistik-perbankan indonesia/Pages/Statistik-Perbankan-Indonesia--Oktober-2016.aspx

Menicucci, E. and Paolucci, G. (2016),"The determinants of bank profitability: empirical evidence from European banking sector ", Journal of Financial Reporting and Accounting, Vol. 14 Iss 1 pp. $86-115$

Molyneux, P. and Thorton, J. (1992), "Determinants of European bank profitability: a note", Journal of Banking and Finance, Vol. 16 No. 6, pp. 11731178.

Pasiouras, F. and Kosmidou, K. (2007), "Factors influencing the profitability of domestic and foreign 
banks in the European Union", Research in International Business and Finance, Vol. 21 No. 2, pp. 222-237

Saeed, M.S. (2014), "Bank-related, industryrelated and macroeconomic factors affecting bank profitability: a case of the United Kingdom", Research Journal of Finance and Accounting, Vol. 5 No. 2, pp. $42-50$.

Short, B.K. (1979), "The relation between commercial bank profit rates and banking concentration in Canada, Western Europe and Japan", Journal of Banking and Finance, Vol. 3 No. 3, pp. 209-219.

Staikouras, C.K., Mamatzakis, E. and Koutsomanoli-Filippaki, A. (2008), “An empirical investigation of operating performance in the new European banking landscape", Global Finance Journal, Vol. 19 No. 1, pp. 32-45.

Sufian., F. and Noor. (2012). Determinants of Bank Performance in a Developing Economy: Does Bank Origins Matter?. Global Business Review. Vol, 13 No, 1., pp 1-23

Sufian, F. and Habibullah, M.S. (2009), "Bank specific and macroeconomic determinants of bank profitability: empirical evidence from the China banking sector", Frontiers of Economics in China, Vol. 4 No. 2, pp. 274-291. 